University for Business and Technology in Kosovo

UBT Knowledge Center

UBT International Conference

2015 UBT International Conference

Nov 7th, 9:00 AM - 5:00 PM

\title{
Advanced Construction Materials for Highway Applications
}

\author{
Altin Bidaj \\ Polytechnic University of Tirana, altinbidaj@yahoo.com \\ Irakli Premti \\ Polytechnic University of Tirana \\ Hektor Cullufi \\ Polytechnic University of Tirana
}

Follow this and additional works at: https://knowledgecenter.ubt-uni.net/conference

Part of the Civil Engineering Commons, and the Structural Engineering Commons

\section{Recommended Citation}

Bidaj, Altin; Premti, Irakli; and Cullufi, Hektor, "Advanced Construction Materials for Highway Applications" (2015). UBT International Conference. 77.

https://knowledgecenter.ubt-uni.net/conference/2015/all-events/77

This Event is brought to you for free and open access by the Publication and Journals at UBT Knowledge Center. It has been accepted for inclusion in UBT International Conference by an authorized administrator of UBT Knowledge Center. For more information, please contact knowledge.center@ubt-uni.net. 


\title{
Advanced Construction Materials for Highway Applications
}

\author{
Altin Bidaj ${ }^{1}$, Irakli Premti ${ }^{2}$, Hektor Cullufi ${ }^{3}$ \\ 1,2,3 Polytechnic University, Faculty of Civil Engineering, Department of Mechanics of \\ Structures, Tirana, Albania \\ altinbidaj@yahoo.com ${ }^{1}$
}

\begin{abstract}
Nowadays cost of highway materials increase every year. In addition, use of marginal materials results in early development of pavement distress, requiring more frequent repairs also rehabilitation, associated lane closures, traffic congestion in high volume traffic areas which increases the potential for construction zone accidents and increased levels of environmental pollution related to automobile emissions. Therefore, there is a strong desire in our country to optimize the use of materials currently used for highway pavement construction and to seek advanced materials that are cheaper and environmentally friendly. It has now been recognized that the age of limitless construction materials and the use of conventional materials in their present form is fast coming to an end, and new technologies need to be developed to continue to support the rehabilitation and reconstruction of pavements. Today, concerns about limited availability and sustainability are driving the search for new and advanced materials for highway construction. In this pap er we describe the potential for considering the use of alternative materials, also encourage the industry to accelerate the development and implementation of products still under development. The materials range from materials under development to recently commercialized materials.
\end{abstract}

Keywords: construction materials, next generation sustainable cement, ecofriendly cements.

\section{Introduction}

Increased traffic, generally limited availability of funds for highway improvement, diminishing raw materials and concerns related to the environmental impact of construction, bring the need to evaluate technologies for a better performance of roads by ensuring that pavements are longer lasting, safer and environmentally friendly. This article is about limited availability and sustainability and also for the search of new and advanced materials for highway construction. The next generations of cements are in various stages of development. Alkali activated and geo polymer cements are already being used on a limited basis and will have higher demand in the next years.

\subsection{Advanced construction materials}

It is important to find advanced construction materials in order to:

* Extended service life.

* Optimized use of locally available materials.

* Achieving environmental benefits as reduced related emissions.

* Reduced work zone, related to traffic delays and safety concerns.

* The use materials that reduce the potential for early failures.

* Reduced costs

* Conservation of resources, support national efforts to create sustainable solutions to minimize impact of construction on the environment.

* Reduced ecological footprint.

\subsubsection{The damage phenomena}


In engineering materials exposed to complex mechanical and environmental loading (e.g. temperature and humidity variation etc.), constant micro structural (or structural depending on material types) changes occur, causing a drop of strength. In general such effects are complex, but at macroscopic scale can be seen as so called material damage. Depending on material type, the damage phenomena can be understood differently, for concrete material damage begins by de-bonding between aggregates and cement. In damage mechanics there is the possibility to distinguish some characteristic types of damage. The most important types are presented below.

Brittle damage

Brittle damage occurs when a crack is initiated without a large amount of plastic strains.

Ductile damage

Ductile damage happens simultaneously with plastic deformations larger than a certain threshold on the graph of stress as a function of strain. It results from the nucleation of cavities due to de-bonding between inclusions and the matrix which causes local plastic instability.

Creep damage

When materials have viscous properties, damage can occur at a constant stress level. Total strains gradually increase and cause irregular cracks.

Low cycle fatigue damage

When materials are subjected to cyclic loading with large stress or strain amplitude values, damage develops with plastic deformation in three phases: incubation, nucleation and micro crack propagation. In case of low cycle fatigue, the damage can be either inter granular or trans granular.

High cycle fatigue

This case is contrary to low cycle fatigue damage. Here, damage is observed for a higher number of cy cles with lower amplitude of stresses or strains. Depending on material ty pe subjected to such cyclic loading, the plastic strain at the meso level remains small and is often negligible. Then damage symptoms can be observed at the micro scale.

\subsection{Next generation sustainable cements}

As sustainability becomes increasingly important in the construction of transportation infrastructure, approaches are being made to reduce the environmental footprint of concrete, which is the most widely used construction material in the world. The key to reducing the carbon footprint of concrete is therefore to reduce the amount of portland cement used, and one way of accomplishing that is through the use of next generation cement binders that significantly reduce $\mathrm{CO}_{2}$ emissions. Although portland cement is a relatively minor constituent in concrete, it is responsible for 85 to 93 percent of the $\mathrm{CO}_{2}$ associated with concrete. Research is going to improve and to develop cements that eliminate $\mathrm{CO}_{2}$. This new category of next generation sustainable cements is still in development. Alkali activated and cements with several other components, will help to obtain low carbon footprint concrete for use in transportation.

The availability of carbon neutral and carbon sequestering cements influence the application in transportation infrastructure, particularly in urban environments where economic incentives through local legislation exist to reduce the carbon footprint. Eco friendly cements are newly developed cement types that are more ecologically friendly than ordinary portland cement. Primarily, these cements are capable of reducing the amount of greenhouse gas $\left(\mathrm{CO}_{2}\right)$ emissions associated with their production, but they are also capable of sequestering and using additional $\mathrm{CO}_{2}$ as part of the curing/hardening process that concrete mixtures undergo. The primary benefits associated with the use of eco friendly cements are their sustainability features and overall environmental friendliness. They incorporate solid waste and sewage sludge, can be produced at lower kiln temperatures, and also absorb and sequester $\mathrm{CO}_{2}$, while also possessing rapid hardening abilities. Once fully developed, ecological cements like Novacem and $\mathrm{SC}^{4}$ will significantly reduce the carbon footprint of the built environment. In addition, other eco cements that incorporate waste materials will help reduce landfill requirements and the energy and $\mathrm{CO}_{2}$ emissions associated with hauling wastes. Improving the strength, also the permeability properties of $\mathrm{SC}^{4}$ will influence positively the longevity of concrete structures and pavements, thus increasing the sustainability of infrastructure. 


\section{Conclusions}

The limited availability is the factor to push for new and advanced materials for highway construction. In this paper we described the potential for considering the use of alternative materials. Next generation sustainable cements will significantly reduce the carbon footprint of the built environment. This could have significant global impact as a way to mitigate the long term effects of global climate change. The adoption of specific elements of cement and performance specified cements, will increase innovation in producing more environmentally benign cements specifically linked to performance.

\section{References}

1. Harrington, D., et al. Guide to Concrete Overlays: Sustainable Solutions for Resurfacing and Rehabilitating Existing Pavements. Ames, IA: National Concrete Pavement Technology Center. 2008.

2. ISO. Environmental Management_Life Cycle Assessment—Principles and Framework 2009.

3. ISO 14040:2006. International Standards Organization. 2009.

4. www.iso.org/iso/catalogue_detail?csnumber=37456.

5. Krantz, L. Jobs Rated Almanac.Sixth Edition. Fort Lee, NJ: Barricade Books, Inc. 2002.

6. Marceau, M., M. Nisbet, and M. VanGeem .Life Cycle Inventory of Portland Cement Concrete 2007.

7. PCA R\&D Serial No. 3011. Skokie, IL: Portland Cement Association. McDonough, W. and M. Braungart . Cradle to Cradle: Remaking the Way We Make Things. New York, NY: North Point Press. 2002.

8. NRMCA. . Pervious Concrete Pavement: An Overview. National Ready Mix Concrete Association. Accessed June 2009.

9. www.perviouspavement.org 